Xu J, Yeh AGO Decoding Urban Land Governance: State Reconstruction In

Contemporary Chinese Cities, Urban Studies, 2009, v. 46(3) p. 559-581

\title{
Decoding urban land governance: state reconstruction in contemporary Chinese cities $^{1}$
}

\section{Introduction}

In the rapidly growing literatures on urban development in China, many authors have emphasized the salient decentralisation of economic governance and the increasingly significant role of local state. It is argued, for instance, that the distinctive decentralised form combined with proper incentives allows local state to play an increasingly corporatist role (Oi, 1992, 1995); that local state is stepping into some form of organization with a great capacity to manage public industry as a diversified market-oriented firm (Walder, 1995); that the empowered local state has directly involved in the market economy through establishment of own business that is genuinely entrepreneurial in the sense of profit-seeking, risk- taking and productive (Duckett, 1998); that the central state, although still politically dominating, has become less relevant in local economic sphere because of a series of reform packages like fiscal reform (e.g. Wong et al, 1995); and that former centrally organized institution is now undergoing a process of 'de-hierarchisation', which gives rise to the ‘territorialisation’ of place-based socio-institutional form in urban development (F Wu,

\footnotetext{
${ }^{1}$ The authors would like to thank five reviewees for their constructive comments and following organizations for their financial support for this project: Zhong Hua Real Estate and Construction Research and Development Foundation Limited in Hong Kong and Professor Francis Lau; The University of Hong Kong Seed Funding Programme for Basic Research (Project code: 200605159005); and Competitive Earmarked Research Grants (CERG) (Project code: HKU 752407H).
} 
2002). These discourses suggest a widely recognised and intensively researched phenomenon in post reform China - scalar shift of the state's functions downwards in capital accumulation and commoditised urban transformation. Whatever their differences of terminology, research objectives and interpretations are a focus on the accelerated re-articulation of state functions downwards to lower level of politico-institutional organization, which leads in turn to a systematic reworking of the traditional statehood under socialism. This downscaled state function is said to invigorate a process of territorialisation through which local state re-consolidates its power with the jurisdictional capacity to regulate all local activities regardless of their affiliation (F Wu, 2002). In this sense, urban development, unlike pre-reform situation, is being increasingly attached to and embedded in places and territories on sub-national scale, i.e. municipality. With these theoretical interpretations, it is tempting, at first glance, to read the contemporary urban transformation in China only as a major consequence of the decentralisation process.

One significant character in these interpretations is that they focus only upon one side of the changing urban governance - decentralisation of statehood. Such analyses neglect a counter-trend in which the central state has de-territorialised and re-hierarchisatized some key functions through state regulatory regime. This counter-trend of state reorganization at least equally contributes to the significance of economic governance nowadays. Neglecting this point may cause only partial understanding of the changing institutional architecture and process of space commodification in urban China. In other words, we argue that the process of decentralisation of economic governance is counterbalanced by the rise of state strategies to control the articulation of scales through which a more centrally 
consolidated power can be achieved.

This argument is elaborated through a discussion of urban land governance which is currently being de-territorialised and re-centralised for better regulation. The trend of recentralisation is not conceived here as the 'legacy of authoritarianism' or 'continuum of state socialism'. Rather, the nature of recentralised state function is redefined by the imperative of market development, making the state fundamentally different from the former counterpart. On this basis, re-articulation of the state function is analysed as expressions of reactive trends to new governance issues. State reconstruction in contemporary cities is not a unique phenomenon only found in China. It is also reflected in the rescaled urban governance in the transition of capitalist state (Brenner, 1999; Jessop, 2002). However, post socialist transition provides a unique experience because of its path-dependent nature. The case of China can therefore, present a good evidence to assess some outstanding features of emerging governance in transitional cities.

This study is an initial effort to examine the state reorganization in China, which is counter devolution that has been widely studied. Following this introduction, section two discusses the perspective to look at state re-organization. Section three examines the contextual changes inside and outside the state that have driven the state to rehierarchisatize and re-centralise its structure in land administration. In section four, re-articulation of government structure is examined, which is followed by a detailed examination of land governance. At the end of this paper, a brief introduction reflects on land governance and its significance for research into urban governance. It is offered to propose that new interpretations of 'commoditised urban transformation', 
especially 'commoditised production of the built environment', should be understood by underscoring the interplay between trends of decentralisation and territorialisation and counter-trends of recentralisation and hierarchisation.

\section{The perspective on state reconstruction}

The aim of this section is to highlight perspectives - how to look at state reorganization in the face of market reform and globalisation. The role of state in transitional cities is an enduring topic. The real issue is not whether the state should play a role but what and how that role should be played (Stiglitz, 1994). Indeed, the thesis of state governing market is not confined to transitional economies. The Keynesian type of welfare state (KWNS) offered a distinctive set of national policies to support mass production and consumption from demand perspective in capitalist cities. The justification of such intervention at national scale is market failure. Jessop (2002) further examines the reconstruction of national territorial space when the capitalist state is transformed from KWNS to the post-Fordist accumulation regime, and to what he describes as the 'Schumpeterian competition state'. The new regulatory regime supports supply-side factors to develop the capacity of structural competitiveness and facilitate labour market flexibility and mobility. This defines a reworking of national territorial space, in which state functions are re-articulated upwards, downwards and outwards so that place- and territory-specific strategies of economic development can be mobilized and achieved. Two of Jessop’s fundamental premises are particularly useful to form appropriate perspectives on state 
reconstruction. One is that the capitalist mode of production is an object of regulation by the state because the market cannot be self-regulating. This regulating state 'comprises an ensemble of socially embedded, socially regularized and strategically selective institutions, organizations, social forces and actions organized around (or at least involved in) the expanded reproduction of capital as a social relation' (Jessop, 2002: 5).

The other premise is concerned with the trends how the capitalist state restructures itself in the face of regime shift and impacts of globalisation and regional integration. The overall trend is the establishment of new scales and arenas for state intervention. Brenner (1999: 447) has argued at length that the state reconstruction as politics of scale can be construed as a sequence of groping, trail-and-error strategies to manage the intensively conflictual forces of globalisation through the continual construction, deconstruction and reconstruction of relatively stabilized configurations of territorial organization. Jessop (2002) persuasively distinguishes three trends (denationalization, destatization, and internationalization) and counter-trends (increased scope for state in interscalar articulation, increased role for state in megagovernance, and interiorization) of state reorganization in capitalist transition. He indicates that these trends and counter-trends should not be deliberately presented in a one-sided and undialectical manner, because they are intertwined with each other. Counter-trends must be viewed as 'reactions to the new trends rather than as survivals of earlier patterns' in the face of globalisation (Jessop, 1999: 26). If China is not excluded from the impact of market reform and globalisation, Jessop’s writings can provide a useful perspective through which to situate the most recent wave of land institutional reform in relation to the newly emergent, rehierarchizatised, and recentralised forms of state configuration. Crucially, Jessop has particularly emphasized the strategic role of the 
national state. It is argued that restructuring of capitalist state should not be discussed in terms of the decline of the national state (Jessop, 2002). Scaled state does not evolve in a zero-sum relationship. Rather, the state is reconstituted to solve the crisis and overcome the hurdles of capital accumulation and social reproduction in order to re-gain its functionality in glurbanization strategies.

In the context of economic transition, state governing society has a new meaning, because the state is more than a market regulator - it becomes essentially a market builder (Wu et al., 2007). In particular, the state intervention carries a different meaning in 'developmental state' (Cumings, 1999; Castells, 2000), in which the state legitimizes itself by prioritizing development (Wu et al., 2007). Castells (2000) argues that a state is 'developmental' when it establishes the principle of legitimacy and ability to promote and sustain development. Inferring from the practice of Japanese industrial growth, the concept of developmental state highlights the role of state bureaucratic organs in establishing strategic alliance with influential business to foster industrial expansion. This finds resemblance with the experience of East Asia industrialisation in which the alternative governance is applied with the state as machine 'governing the market' (Wade, 1990; Wu et al, 2007). The concept of developmental state has immense appeal to scholars studying China where state intervention is strong, but views are divergent on to what extent the Chinese government is 'developmental'. Zhu (2004) describes a local state that is so 'developmental' in nature that its pro-growth position undermines the capacity to exercise effective development control. Wu et al (2007) argue that Chinese state moves away from resource distributor to market regulator, and now finally to a more entrepreneurial type of market actors. Thus, local corporatism that prevails in China is 
different from the developmental state which often presents at the national level and controls a set of policy parameters with greater national 'sovereignty'.

Applying regulation theory to the context of China's transitional cities, Wu et al (2007) further situate the state reconfiguration in the transformation of the regime of accumulation. Previously, socialist regime was characterized by extensive expansion of the means of production, constrained consumption, and forced organised labour process (Wu, 2003). The new regime after the economic reform is now featured by intensified targeting of cities as strategic sites for accumulation strategies and regulation. Whereas the pre-reform regime emphasized socialist industrialization through redistributive function of the central state, contemporary state regime involves re-conceptualization of the city as the means to overcome the constrain of accumulation through 1) prioritizing scale for intensive accumulation, e.g. by increasing the level of urbanization and encourage rural-urban migration, and reinforcing central city's role in metropolitan governance; 2) commodifying urban space through land and housing market; and 3) adopting global-oriented production through foreign investment and joint ventures (Wu et al, 2007).

In conjunction with the shift of regime of accumulation, there is a reworking of state territorial space and function. Chinese state has to face an increasing social complexity which has weakened its governing capacity. Rather than retreating from urban functions, the state incurs a re-articulation of functions to insert a more sophisticated structure in local economic governance. With ample evidences, Wu (2002) concludes 
It would be too simplistic to understand the economic reform as a total retreat of state power from economic and social life. The dismantling of the economic command system is undeniable. The state apparatus has abandoned direct allocation of production materials, capital, land, and, to a lesser extend, the workforce, while consolidating its regulatory power at the level of localities (Wu, 2002: 1080).

In fact, such role of the state in economic governance is seen critical in the context of non-market society for it helps and facilitates, among others, the creation of market institution because the market cannot be perfectly self-regulating. For example, the state abolishes in-kind housing allocation and administrative land allocation to pave way for market institution (e.g. Wang, 2001; Wang et al, 2005). It is also directly involved in knocking down old neighborhoods and making prestigious spaces to create market demand (e.g. He and Wu, 2005; Xu and Yeh, 2005). This observation leads to the first implication - with a sophisticated governance structure, decentralisation does not mean reduction of state intervention and relaxation of control.

The second observation is closely related to the role of the central state as a strategic site of economic governance. As discussed, it is widely believed that the primacy of the central state now declines in local economic growth. Retreating from local governance was purposely designed by the central state during the early reform period. Qian and Weingast (1997) once observed that China's central government has explicitly limited its information as a way of credibly committing the centre not to repeat the pernicious behaviour of the pre-reform era. For example, the central government allows local governments to maintain various 'extra-budget' and 'off 
budget' account; limited knowledge about these budgets commits the central government not to tax them, which in turn encourages local governments to generate prosperity and revenue (ibid: 86). Reviewing recent development policies, it would be too naïve to discuss state reconstruction only in terms of the decline of the central state and the rise of localities. Reasserting central state function is now also purposely designed to regulate local economic governance. For instance, in 2006, the central government required the local 'off budget' land leasing income be totally incorporated into budget account. This will significantly subject substantial land income to a high degree of oversight of the central state and scrutiny of the people's congress. In this regard, the perspective of Jessop to look at state reconstruction is particularly useful by underscoring the interplay between trends and counter-trends, state restructuring should be represented as an open-ended, conflicutual process rather than as an unlinear transition from one state form to another (Brenner, 2003).

Another key issue, in the present context, is how to look at the nature of state intervention. That the state continues to play a role in economic development at both central and local levels should not be read as the 'legacy of state socialism'. Rather, there is a substantial change of the nature of such intervention (Wu et al, 2007). W Zhang (2000) assesses the transformation of Chinese state from an anti-market totalitarian state into a largely pro-business authoritarian state. Particularly in the sector of developing landed property, a number of scholars have also identified a qualitative new form of state that commodifies the 'place' as space commodity (e.g. Yeh and Wu, 1996; Yeh, 2005). This consideration, together with those mentioned above, provides a state-theoretical perspective on which to interpret the re-articulation of state function in landed property. 
Urban land governance is an excellent example to study the state re-articulation. It is one of the two key tools of controlling space formation in China. The other is development control. Land use control is performed by land departments under the Ministry of Land and Resources, while development control is undertaken by city planning bureaus under the Ministry of Construction. They are two systems with different functions. The 1989 City Planning Act builds up the development control system and permits a large discretion of local state to grant or reject development rights within a defined planning area. The system has changed very little since 1989 and represented an essential government function of territorial political-economic institution. But even with such a system, commodification of urban space still leave cities spoiled in many cases, whether by state-initiated large scale development activity, the dereliction of idle sites, the rampant illegal land uses, or the apparent irrationality of new buildings unrelated to surroundings. These outcomes raise the question of whether city planning is implicated in regulating the market transition (for details on development control failures see Xu and Ng, 1998; Yeh and Wu, 1999; Ng and $\mathrm{Xu}, 2000 ; \mathrm{Xu}, 2001)$. Regulatory land control is thus arguably becoming an important alternative way of the state's involvement in space commodification (for example see next section).

\section{Changing conditions inside and outside the state}

3.1 Changing conditions inside the state

The conditions upon which land politics are developed are found both inside and 
outside the state. There are three major factors inside the state that drive the trends of re-hierarchisation and re-centralisation of statehood in land governance.

The first factor associates with decentralisation and local disobedience. Chinese governments, both modern and historic, have been dogged by problems of local compliance (Wedeman, 2001: 59). Since the economic reform, local disobedience becomes more difficult to control for state functions are increasingly devolved to low tiers of governments. During the pre-reform period, production was organized on a 'sectoral and hierarchical basis'. Local state was not entitled for territorial governance. It only followed central orders and provided infrastructure and services that could not be covered by the hierarchical system to sustain socialist regime of production. After the economic reform, local economic activities are more territorially organised and involve greater emphasis on economic growth, capital intake, and competitiveness. Under the new regime of capital accumulation, the main concerns of the central and local state are now partially departed. For the central government, the concern is how to restructure its regulatory tools to exercise enough control of discretionary local state and market to ensure that its outcomes are within the manageable scope without destroying local incentives as well as the very mechanism of the state. For the local governments, the concern has become how state institutions can improve the competitiveness of economies and sustain growth in the face of market reform and globalisation. For example, there is a growing local interest in creating new institutions (e.g. development zones, science parks, university towns) to open more space for capital accumulation (Cartier, 2001; Wei and Leung, 2005).

The transfer of powers to low levels not simply leads to empowered local state, but 
also creates a delicate and uneasy relationship between the central and local government. Zhang (1999) observes that the centre no longer feels confidence enough politically to rely on the provinces to collect revenue. Xu and Yeh (2005) show how the local state circumvents central orders and goes beyond legal and budgetary constraints to mobilize resources. Wedeman (2001) reports the ineffectiveness of the central government or supervisory centre in perfectly differentiating between simple 'incompetence and wilful disobedience of local state, because the structure of the state enables cadres to engage in strategic disobedience'. These are among factors that drive the centre to recalibrate state regulatory regime to ensure that local state's expansion should not jeopardize its governing capacity. However, reasserting control by the centre is not an easy task. The Land Administration Law has granted the property right of urban land to the local governments although as the principal owner the centre extracts a small percentage of land leasing premiums. The City Planning Act also gives them the power of initiating and issuing development permits. As a result, the local governments control both the ownership and the development right of urban space (Wu et al, 2007). But the central and local states have different perceptions over land issues. To the centre, the task is to promote effective land use and preserve farmland through establishing a full-fledged land market and controlling rapid urban expansion. To the localities, pro-growth and expansionist policies are essential to sustain growth; and the implementation of such policies require land, and lots of it. This discrepancy of perceptions results in tensions between central policies and local practices.

For example, the central state has repeatedly issued policies since the late 1990s to increase the transparency of land market, but land is still transacted in non-transparent 
way. The Land Administration Law was amended in 1998 to enforce a strict land use control. The 'Directory of Allocated Land' was announced in 2001 to abolish administrative land allocation to commercial projects. In March 2002, the Ministry of Land and Resources (MLR) issued No. 11 Decree ('Regulation of Granting State-Owned Land Use Right by Tender, Auction and Quotation’) - which required all land for business purposes (commerce, tourism, entertainment and commodity housing) be transferred publicly after 1 July 2002 either through tender, auction or quotation $^{2}$. At the same time, the Decree still permitted negotiated conveyance for industrial projects to allow certain flexibility and buffer local resistance. In March 2004, MLR released No. 71 Decree, which sets 31 August 2004 as the deadline for all cities to ban negotiated conveyance for commercial development. In November 2004, the State Council issued the 'On Deepening Reform and Strengthening Land Administration', which is viewed by many as the strictest land policy ever to reiterate the orders of No. 11 and No. 71 decrees.

However, under prevailing land politics (e.g. Hsing, 2005), enforcement of these policies is very difficult. The No. 11 Decree, while implemented officially, had been overlooked by local state (for the detailed case of Beijing's disobedience see Gong, 2004 and Jia, 2004). The disobedient localities have forced the central state to make more circulars to reiterate the orders of No. 11 Decree after 2002 because its target to establish a more governable market is hardly fulfilled. In 2004, among 257,920 hectares of land supplied to users nationwide, 24 per cent (or 62,054 hectares) was

\footnotetext{
${ }^{2}$ Tender and auction have been documented extensively (e.g. Yeh and Wu, 1996). 'Quotation' (gua $p a i$ - literally hanging plate) is a relatively new method of public bidding in land leasing. It is a process whereby a city government publishes a notice disclosing the terms and conditions for granting land use rights, accepts quotations from bidders and updates prices in the listed notice accordingly. The winning bidder is the one who offers the highest price at the end of notice period which is set at least 10 working days.
} 
administratively allocated to them, while 70.4 per cent was leased out through negotiation, tender, auction or quotation (MLR, 2006). Among total leased land, negotiated conveyance still accounted for more than 76 per cent with a mere 0.8 per cent for tender, 8 per cent for auction, and 16.9 per cent for quotation (MLR, 2006). Of the 129,083 hectares of leased land through negotiation, 66 per cent was provided to industrial uses, with almost 24 per cent for commercial and commodity housing projects. These figures suggest central policy failures as land is still transferred non-transparently in most Chinese cities. Under-table transactions (e.g. misallocation of land resource, land abuse, hoarding, rent-seeking, and corruption) and ungovernability caused by non-transparent land deals are widely observed and extensively analyzed (e.g. Yeh and Wu, 1996; Xu, 2001; Zhu, 2002; Lin and Ho, 2005).

'Strategic disobedience’ also enables cadres to circumvent central orders. Ho and Lin (2003) reports that local cadres would expand their approval authority by dividing large land parcels into smaller ones and multi-year projects into 'independent' annual projects. $\mathrm{Xu}$ and Yeh (2005) use the case of Guangzhou University Town to further confirm this observation. Elsewhere, many scholars focus on the unscrupulous land expropriation that leads to sprawling urban expansion (Cartier, 2001, T Zhang, 2000, Deng and Huang, 2004). Rapid urban expansion jeopardizes the national policy for farmland protection and compact land use, but the central state only has few tools available to curb this trend. Urban master plan is one of such tools. Master plan is the only urban plan that requires central authorization, while other local plans can be subject to municipal approval. As such, master plan is a major contested terrain between the central and local government. For example, the master plan (1996-2010) 
of Guangzhou was first sent to the central state for approval in 1996, but rejected by the latter because it proposed a large urban expansion, contravening central policy to limit land use. But, restricting local expansion through the prolonged central-local negotiation over master plan is not effective. At the time when Guangzhou annexed Panyu and Huadu in 2000, two county-level cities, to expand its boundary, the central state had not yet authorized the master plan. The city was then required to prepare alterations and resubmit the plan in 2004 to accommodate changes caused by administrative rescaling. Adding to this complexity, regulatory plans are not statutory in most Chinese cities for good development control. This means that the centre has to rely on land administration as an alterative approach to restrict local expansion.

Failture of affordable housing programme is another case of local disobedience. Central government has urged the local state to ensure land supply for affordable housing, but fizzled. There is still a huge affordable housing shortfall (for more details see Wu et al, 2007). Many of the low-income families (e.g. laid-off workers) in urban areas have to fight for the few affordable flats available despite a surplus of luxury housing in the market. This situation causes a strong feeling of injustice among ordinary residents. The availability of land for affordable housing is thus a key political issue. It meshes with national political agendas concerning urban poor and their housing needs and the local development pressure arising from the land demand for high-end commercial housing.

The second factor that drives state reconstruction arises from the emerging 'public-private partnership' (PPP) and the formation of 'growth coalition'. While decentralisation de-hierarchisatise and re-territorialize state’s activities, PPP involves 
the re-articulation of public-private divide in commodifying the built environment. $\mathrm{Xu}$ and Yeh (2005) argue that substantial land and financial demands of urban development have made it financially not feasible for the public sector alone to undertake urban construction, and thus encourages the building of coalitions based on money-generating sectors such as property. Other studies (e.g. Zhu, 1999; Zhang, 2002; Luo and Shen, 2006) also observe the formation of 'Chinese growth coalition' around landed property. It is found that local state often circumvents regulation and overexploits land resource and credit to support large projects. Developers build commodity housing as a speculative activity, taking on the whole process from purchase of the site, through construction of the dwelling and estate layout to final marketing of the finished house. They can also speculate by holding land stock. Banks as the major financiers are keen landed interests. Over 80 per cent of funding for land purchase and property development comes from direct and indirect bank lending; and 75-97 per cent of consumer credit is for individual home buyers (Liu, 2004). Homeowners are keen interests too because of their market interests in the accumulative potentials of own properties. These observations seem to suggest that Chinese cities are restructured by a coalition of local state and growth entrepreneurs. They come together to pursue an agenda of urban growth and intensification of land use. This interpretation may sound similar to the coalition politics in advanced capitalism.

However, we argue that the discussion of Chinese 'growth coalition' has to be situated in the state-driven land politics. Rather than viewing the state as one actor among equals, we need to understand that because the state itself is becoming a market actor, it tends to replace the market and monopolize political and social resources that are 
not easily available to other actors. In developing a real estate project, state input is essential at all critical stages from land expropriation, resettlement, to the usage of credits for getting loans. Large property projects are proposed as vehicles for materialisation of local development strategies. A good example is how Shanghai government wilfully disobeyed central orders to tighten monetary policy towards real estates loans. Shanghai government required large state-owned enterprises like Shanghai Jishan Petro-Chemical Corporation, Cable TV and Baosteel Group to lend money via banks to property developers when central policies order tightened loan application to real estate projects. So, these developers could overcome the hurdle of capital shortage and still keep commodity housing price at a high level (Yi, 2006). Recently, the city was disgraced by the abusive use of social pension accounts to fund investment in the booming real estate. The reason is simple - the debt-burdened local finance in Shanghai resulted from massive urban construction will suffer if a downturn in real estate sector leads to slow growth of land income (Yi, 2006). Clearly, the state not only uses market instrument (e.g. financing) to solve its own crisis but also becomes an active yet unparalleled 'market actor' in the marketized political economy.

There is nothing new that government relies on other agencies to assist them in achieving state objective or extending state power beyond the formal government apparatus. The thesis of 'growth machine' (Logan and Molotch, 1987) interprets how a network of actors that cross-cut and unify the state functions and connect them to other social forces in pursuing growth. But this reliance has a different manifestation in China because the local state can replace and monopolize the market to enhance its capacity to secure its objectives, which defines the fundamental departure of Chinese 
'growth coalition' with the North American version.

Globalisation and competitive strategies present another key trend to reshape land politics. Market reform and globalisation have two significant results for policy regimes in China. They re-configure the context of state policy process which has expanded to include a wider range of extraterritorial and global factors (see Wu, 2006). They also give rise to the development of 'entrepreneurial city'. Both results are reflected in economic policies as the state becomes more concerned with local, regional and even global competitiveness. Current studies reveal that the formation of territorially-based entrepreneurialism is a state project which allows the state to tap the market and restore its role as active promoter of economic development (Wu, 2000, 2003; Xu and Yeh, 2005). It is also found that marketization does not reduce or eliminate the central state's functionality. But in the context of state-driven land politics, building entrepreneurial city can be undertaken in a way that goes beyond the legal and budgetary constraints of local state, which is running out of control of the distant centre.

\subsection{Changing conditions outside the state}

Market reform and globalisation have created forces beyond the formal state apparatus. When these forces fuse with territorial discretion or are simply out of control of the government system, state intervention has to be re-established through either re-centralising key functions or extending state power beyond the formal apparatus. Here, we distinguish three forces outside the state which are closely linked to land politics in China: real estate capital, marginalized people, and fragmented 
space formation.

Real estate capital can be categorised into three types: domestic capital, foreign capital, and individual capital. In developing landed property, domestic developers have to secure two critical resources, i.e. land and capital. From the land supply side, many of them can have negotiated land deals with the government. From the capital supply side, bank loans make up a considerable portion of investment in a real estate project, while developer only contributes little (for details see Liu, 2004). Commercial banks bear the most market and credit risks in real estate development since they extend lending to the whole process of land and housing development, which include loans for land purchase and home-building, working capital loan for various building firms, and land reserve loan. This leads to the softening of the budget constraints of developers because they have unduly shifted much of their risks to banks, or even to construction companies or home buyers (Chen, 2004).

Unlike domestic capital, foreign investment is relatively immune from Chinese credit curbs. In 2005, more than 192 billion US dollars was invested in real estate sector, among which 12 per cent came from overseas affiliated firms (SSB, 2006). But overseas investors have a hard time land-banking not only because the government is very sensitive to the idea of foreign developers speculating on land, but also because they lack personal relations with government authority unless they partner with local developers with ample land resources (Daily Times, 23 August 2004). Nowadays, the significance of foreign capital is far greater than merely contributing to capital circulation in landed property. Foreign investors are key buyers of offices and commodity housing. A combination of low interest rates and expectations of further 
appreciation of renminbi have caused inflow of overseas venture capital into China's property market (for the case of Shanghai see Coliers International, 2006). In 2005 alone, foreign investors spent 3.4 billion US dollars in purchasing property in China (China Broadcast, 12 July 2006). The percentage of foreign investment in high-end housing projects soared from 7 per cent in 2005 to 36 per cent in the first half of 2006.

Unlike what was suggested by scholars during the 1990s (Wu, 1999), individual capital is no longer a passive agent largely unrelated to demand and supply of commodity housing. Recent studies (e.g. Zhao and Zhang, 2002) reveal a growing importance of the purchasing power of individual home buyers as a result of wealth increase of the public. The role of the public in developing landed property has expanded from purely consumption to speculation (for cases on speculators from Wenzhou, Shangxi and Pearl River Delta in Guangdong, see Liu, 2004; Ren, 2006; Zhao and Zhang, 2002), which proves to be a thorny governance problem.

Land development in China has been accompanied by rising marginalization and escalating social stratification. This is the second force outside the state to reshape new land politics. There are two critical issues here: the forced demolition and eviction prevailing nationwide (see Miao, 2003 for a detailed case on Beijing; Wu, 2004a; Ding, 2004), and the inaccessibility of urban poor to landed property (see Chan 1996, Chan and Zhang 1999, Solinger 1999, Fan 2002, W Wu, 2002; Wang, 2004). Wu (2004b) argues that unlike situation in most other developing countries, marginalization in urban China is not a result of economic failing. Rather, the root of marginalization is institutional. He uses the concept of 'poverty of transition' to explicate marginalization as a result of disjunction between the old institutions and the 
new transitions of urban development. In this sense, tackling problems caused by marginalization has to be accompanied by key politico-institutional restructuring through which broader transformations of state spatiality can be achieved.

Fragmented space constitutes the third force to shape new land politics. Wu et al (2007) point out that post-reform space commodification leads to a new spatial order characterized by redeveloped urbanity and multi-centred urban structure in a fragmented and sprawling context. Transforming urban space has been actively pursued by two radically different manners: 'spontaneous' land conversions that break out government plans and state-led renovation through CBD formation and flagship redevelopment projects. The former often involves illegal land transactions or changes of land use without planning permission (e.g. Ma and Xiang, 1998; W Wu, 2002; Zhou, 2002; Qian and Chen, 2003; Yeh, 2005), while the latter frequently blends local governments with private sector in an important partnership to create prestigious urban space through massive demolition and residential relocation (e.g. Gaubatz, 1999, 2005; Wu, 2000a, 2000b; Xu and Yeh, 2003, 2005).

Spontaneous land conversion was once identified as a major factor causing spatial disorder in urban China (e.g. Yeh and Wu 1996). It brings about a situation where the development of commercial space is not constrained by the supply of leased land (for a detailed case study on Huaqiang Road North in Shenzhen, please see Wang and $\mathrm{Xu}$, 2002). However, state initiated projects (e.g. CBD, convention and exhibition centre, and large urban renewal) and organized expansion (e.g. development zone and university town) have greater impacts on urban physical form and social space formation in recent years. While these projects do exalt urban image, they are often 
undertaken at a high cost to existing communities, and in many cases simply resulted in destruction of vibrant neighborhoods (e.g. courtyard house in Beijing). To create financial feasibility for redevelopment, local state may use the tactic of linking renovation of old urban areas to conspicuous consumption (for a discussion on the case of Shanghai Xintiandi sees He and Wu, 2005). Outbound extension of city boundary serves the purpose of expansionist policies to open up new venue for capital accumulation. In this sense, state actions can be more detrimental to urban space than unregulated land conversion.

To sum up the changing conditions within and outside the state, we notice that a powerful tendency of fragmentation and decentralisation is underway. The territorialisation and mobilization of local economic initiatives generally entails the transfer of power to the local state. The destatization involves a shift from the central state dominance towards various actors and levels of partnership in land development. Outside the state, growing forces of social complexity have weakened the governing capability of the state. This has raised two concerns. One is to tame local discretion within the state apparatus, while the other is to incorporate ungovernable features beyond the state system into regulatory control. These are extremely difficult tasks when the local discretion fuses with non-state forces (e.g. non state capital). The approaches of territorialisation and decentralisation in urban governance may not always be an effective institutional medium for good state capacity. By contrast, we shall argue that the state re-articulation since the late 1990s has represented attempts by the central state to maintain some measures of regulation both functionally and geographically over the increasing fragmentation that underpins local economic governance, especially land governance. We now turn to 'state re-articulation' in 
particular so as to characterize the new emerging features in land governance of Chinese cities.

\section{Rearticulating the government structure}

In this session, we investigate how the central state attempts to retain control over the articulation of different spatial scales. We emphasize the emerging structure of re-centralisation and reconsolidated hierarchical system in local economic governance. Decentralisation of statehood does not necessarily mean the decline of central state. The central government still manages issues of vital national interests (for a list of central functions see Wu et al, 2007: 122-123). Even though most social and economic responsibilities have been delegated to localities, the central state, particularly through its key authorization function in large projects, have significant role to play in local economic governance. The approach is 'top town', involving attempts by central government at strategic distribution of economic activity. One recent example is the site selection for the first overseas general assembling plant for Airbus A320 series aircrafts in 2006. Tianjin was one of the four Chinese cities to compete for this project which amounts to a total investment of 8-10 billion euros. Other three candidates are Shanghai, Xi'an and Zhuhai. When Airbus first started its selection for the plant site, it preferred Zhuhai, a special economic zone in southern China. But after more than six months of negotiation with the State Development and Reform Commission (SDRC), the company finally decided to choose Tianjin as the winner. Before the final selection was determined, the SDRC had a long talk with Airbus on how the company's future strategy might benefit from the promising growth of Bihai New Area in Tianjian, which has been brought into national 
development strategy ${ }^{3}$.

Being a national hub for certain function (e.g. logistics and port) that is incorporated into state development plans (e.g. National Five-Year Planning) is an extremely important local strategy to obtain central policy inclination and allocation. Once a national status is affirmed, it is easier to attract overseas investment. In a recent example, Liaoning Province in Northeast China has successfully lobbied the central government to approve its plan of developing Dalian - a port city in the province into the Northeast Asia Shipping Centre. The Ministry of Construction then quickly came up with ten concrete policies to support the building of Dalian Shipping Centre, which is now a national strategic plan. In fact, reconstructing economic-regulatory institutions to attract central attention has become a major issue ever. As intercity competition for national status is escalating, provinces believe that creating new regional space of economic regulation is a better way to stand out strategically because the Pearl River Delta, Yangtze River Delta, and now the Tianjin Bihai New Area are all successful examples to follow. As of the late 1990s, there have been many newly emergent forms of regional cooperation, such as the Northeast Six Cities Coalition, Guangxi Beihai Bay, and Fujian West Taiwan Strait Economic Region. One of the most strikingly novel characteristics of these forms of regional cooperation has been their explicitly competitive orientation. Proposals have been justified as a means to position own province strategically within state development plan. In contrast to the 1980s, in which debates on regional cooperation (e.g. the Shanghai Economic Region) simply focused on the issues of administrative coordination, current discussions of cooperation of city-regions have also been oriented towards the

\footnotetext{
${ }^{3}$ Interviews with government officials in Beijing, Guangzhou and Zhuhail.
} 
overarching priority of strategic repositioning in a context of a perceived intensification of inter-place competition for central policy inclination.

From another perspective, the central government guides local administrations through policies, plans and assigning tasks to local governments. However, the central government has lost some control in the economic field. Provinces, for instance, were constitutionally of the same administrative level with central government ministries. This means a province may challenge, overrule, or ignore decisions made by a ministry. Similarly, a ministry cannot rule over a province because they are the same rank. This posed a problem for the centre because it has gradually lost independent means of enforcing its authority to prevent localism or impose nationwide standards. As a result, starting from the early 1990s, China began to reform its central administrative organizations in order to enhance their roles in economic regulations. For example, the State Land Management Bureau, the predecessor of the MLR, was set up to replace trivial land offices under other ministries. Another reform is to restructure some institutions of the centre state in the local territory, in a way similar to the federal institutions in the US, to avoid local state interference. One example of this reform has been the People's Bank of China which in 1999 abolished all provincial and local branches and created regional branches spilled over provincial boundaries. A similar reform has been suggested for land administration.

To sum up, the central state still serves as an important level of economic regulation. It has also been an essential institutional focal point around which the various administrative reforms have been articulated. This may be understood as political strategies of the centre to reassert its functional importance to the local process of 
economic governance, even though the dominance at the national level is being decentralized.

However, central state has to convey instructions downwards via provinces. Provinces are theoretically subservient to the central government, but in practice they have great discretion after the economic reform (for a list of central functions see Wu et al, 2007: 122-123). Their actual power has created so called 'federalism with Chinese characteristics' (for definition of this term and its consequences see Montinola et al., 1995). In the old days, imperial government suppressed localism and warlordism by veering provincial borders away from cultural or geographical boundaries. Nowadays, the central state achieves the same goal by strategies like reassigning post of key provincial leaders. In view of the widespread local discretion in land use, the central state decided to re-centralize land administration to the provincial level (see next section for details). Provinces are supposed to keep a watchful eye over local land uses. But in many cases, they cooperate with municipalities under their jurisdictions to circumvent central rules and national land use regulations (for a case on Tieben see $\mathrm{Xu}$ and Yeh, 2005).

Although the central and provincial states formulate most urban policies and oversee their implementation via a carefully designed hierarchical structure, it is largely the municipalities that stand in front of everyday activities in building cities. The role of cities in the overall economic dynamics in China is widely acknowledged. Central cities are particularly outstanding. There are normally five tiers of cities at provincial, sub-provincial, prefecture, sub-prefecture and county levels. Cities at different levels do not enjoy the same power. They have been delegated different powers according to 
their status. For example, provincial-level cities (Beijing, Shanghai, Tianjin and Chongqing) enjoy the same administrative status and power as provinces. They can authorize rural land conversion for urban construction purpose, which is a power other cities do not have. Sub-provincial cities are given a level of power higher than a prefecture, but still lower than that of province. Such special status means a high degree of autonomy within their provinces. They are thus relatively out of the control of provincial governments.

To curb municipal discretion, there have been calls to reform the current administrative divisions. The National 11th Five Year Plan has proposed to abolish the prefecture level cities in order to remove an extra level of administration between the province and county-level divisions to reduce the distance between the grassroots and the government. In practice, regrouping of territory to achieve a more centralized control in fragmented metropolitan region is a key strategy of municipal reform nowadays. The 'big government approach' that favours municipal annexation, merger and consolidation is widely adopted (for a detailed case on the Yangtze River Delta see Zhang and Wu, 2006). Metropolitan reform through consolidation represents an important instance of a new locational policy that privileges expansionist priorities such as economic growth and structural competitiveness to gain control over critical land resource.

Below municipalities, districts are the lowest level of government entitled formal function in land governance. With limited resources and administrative capacities during the pre-reform era (Wu, 2002), districts now enjoy a wide range of government responsibility (for details of historical development of districts see Hua, 2000; for 
expanding functions of districts see $\mathrm{Wu}, 2002)$. However, it is necessary to caution against treating districts as if they were identically granted the same power. In Shanghai, district planning and land departments have much power in development control and land use administration. They are under direct administration of district government. An extreme case is Pudong District. Although its status as a district would define it as county-level, the district head of Pudong is given sub-provincial status and related powers. In other words, it is one and a half levels higher than what would normally be. In Beijing, land use and planning functions are mainly concentrated at municipal level, while districts are merely degenerated to agencies to implement municipal decision. In Shenzhen Special Economic Zone, the government abolished district branches of land administration and planning control to allow municipality full charge of all matters regarding these two key functions, spilling over district boundaries. Guangzhou is an intermediate case with districts having more power than counterparts in Beijing but less power than those in Shanghai. In short, districts may be presented with different problems; and they have different capacities to address these problems and reorganize themselves in response.

In addition to the hierarchical system of government structure, enclaved space represents a different approach towards emerging state power. 'Enclaved space' has been interpreted differently. Ong (2006) captures enclaving as a process of creating a galaxy of differentiated zones (e.g. technology zones) unevenly integrated into the structures of state power and global capital. Enclaves are expressed as a new configuration and structure of development. Using the case of port-FEZ bundle in Tianjin, Wang and Oliver (2006) indicate how the particular bounded spaces lead to the creation of enclaves that consolidates a spatial 'splintering' effect to alienate them 
from their surroundings. These discussions are suggestive about the differential application of state power. Prominent examples include economic and technological development zones, special zones and industrial parks, that in recent years have been under full-fledge campaign to transform urban structure. These spaces represent a different structure of state intervention, and have long provided an analytical challenge to conceptions of urban development. They came to occupy a lynch-pin role in local political economy in the 1990s, with the designated preferential policies that give them both a virtually unprecedented potential for fast growth and a key role in linking local politics with global capital. In the rather basic material terms that are our focus here, this has been productive of a highly segmented city-form.

Special zones have independent land use and planning power. In many cases, municipal land and planning departments simply cannot extend their power to the zones. As such, setting up zones has been used as an 'institutional tactic' for municipalities to bypass tight central control. As 'zone fever' spreads quickly around the country, the central state stepped in to order termination of land conversion for development zones in 2004 as a key policy change to limit land supply of municipalities (for the consequence of this policy in Beijing see Xinjingbao, 24 August 2004; in Guangdong see Yangcheng Evening News, 2 September 2004). To retain control over the articulation of different powers of enclaved spaces, the central state has carried out institutional reforms (e.g. dismantling zone land and planning department) to enhance its role to oversee the development of various 'enclaved spaces'.

Our discussion in this section suggests that decentralisation engenders the space for 
local resurgence, but it also extends the scope for the central state to meditate the increasing complexity of local scales of actions. While local institutions may have wider range of activities that they undertake and seek to influence, and while the central state may have less formal responsibility, the latter could retain a key role in the process of local political-economic governance. We now turn to examine the trend of re- hierarchisation and recentralisation using land governance as an example.

\section{New land management system}

Land management is an essential government function that is performed through the tiered government system. Opposing to the general theme of decentralisation of urban governance, land administration has undergone a recentralisation process, in which the central state has actively promulgated various land policies to restrict local behaviors. In addition, recentralisation occurs in conjunction with hierarchical control of land administration through which the central state attempts to use top-down vertical link to coordinate and supervise the increasing complexity in land development. By underscoring the interplay between the general trend of decentralisation in urban governance and the counter-trend in land administration, we attempt to represent the subtlety in governing land development: jurisdictional power of local state contravenes the tightening of land use control of the central government.

\subsection{Re-hierarchisation of land administration}

Re- hierarchisation of land administration has been undertaken in three major stages. The first stage was marked by the end of work units in land administration. This 
happened in conjunction with major institutional reforms initiated by the central state. Before economic reform, 'land bureaus' had been put under different agricultural departments mainly in charge of rural land such as wilderness and state-owned farms. Urban land was under a separate system. There was no single organization specially designed for urban land management at both central and local level. Rather, this function was scattered among work-units under the jurisdictions of discrete sectoral departments. The dispersed urban land administration led to cultivated land loss (for details see $\mathrm{Wu}$ et al, 2007). To rectify this problem, the State Land Management Bureau (SLMB) was set up in 1986. In the same year, the Land Administration Law was promulgated. This was a breathtaking event. SLMB was an independent organization under the State Council to execute unified management of urban and rural land. Local governments at or above county-level are required to set up land departments in charge of land administration. Township governments were responsible for township land administration within their boundaries. Work-units were legally denied the privilege in land disposal in the first stage of institutional reform.

Setting up SLMB helped to form a five-tied land administration system at central, provincial, municipal, county, and township levels, under which local governments, especially municipalities and counties, were given much power in land disposal. Transferring the land management power from work-units to local governments can certainly create a favourable condition for local growth and better land use control. But it is also required that upper level land departments have to supervise the lower level. This means that local land department is virtually under dual leadership. Territorially, it is under the administrative control of local government, but hierarchically it is subordinated to technical supervision of corresponding agencies at 
higher level. Administrative control and technical supervision has fundamental difference. The former refers to the statutory power in cadre appointment and fiscal allocation, while the latter means the capacity in sectoral oversight. Because the city land department is administratively subservient to the municipal government, there are many ways by which the government can limit the actions of the former. The key cadres of the department, for instance, can be appointed directly by the municipality. It also depends on the municipality for finance. There are also other supervisory methods such as advice and orders given by the municipal government to the land department. Comparably, the technical supervision is a much weaker way of control.

Setting up SLMB and empowering local state did not lead to the end of land use abuses (for details see Ye, 2004). The discretional local governments were directly involved in many illegal land conversions. Top central officials thus urged to transfer land use authorization power from municipalities and counties to provinces. In 1998, the Ministry of Land and Resources (MLR) was set up. It is the central authority responsible for land administration. This 'super-department' has combined the former state bureaus and ministries of land administration, geological and mineral resources, maritime, and surveying and mapping, and is charged with the responsibility for the 'the whole range of functions of planning, management, conservation and utilization of nature resources'. In the same year, the Land Administration Law was amended to re-centralize major land authorization power (see following for details). At this stage of reform, the central state tried to retain some important influence over land policies such as arable land conservation by restricting discretions of municipalities in land development. 
However, the new management system has not achieved the expected outcomes because of countermeasures at bottom to resist central orders (for details see China Information News, 20 February 2004). The State Council then decided to instigate the third stage land administration reform in 2003. It is required that 'hierarchical land management system' (HLMS) should be established by the end of 2004 at all governments below provincial level. Under the HLMS, key cadres of local land departments should be appointed by land departments at the next higher level rather than by local governments. The 'hierarchical linkage' is thus strengthened. Because of this change, the provincial land authority should have a structure of regional agencies, which can act as 'the eyes and ears' of the land authority. However, land departments are still dependent on local finance. In this sense, a municipal land department is subordinated to the provincial land department in terms of personnel and technical guidance (hierarchical) but still dependent on the municipality for finance (territorial). One cannot deny that the municipality has, in effect, a controlling role over land issues through its financial responsibilities. As the HLMS reform is only applied to governments below provincial level, it has been called a partial reform. This has two implications: first central-provincial relationship remains unchanged, and second land administration of municipalities at provincial and sub-provincial level remains untouched.

\subsection{Recentralization of land authorization power}

Recentralization of land authorization power is reflected in the changing division of labors among hierarchical agencies in land administration. To understand the foundation of current land administration in a once centrally-planned economy 
requires a brief interpretation of how land use was administered in the former system. The land development process in a centrally planned economy was featured by both concentration and fragmentation. The decision-making was highly centralized within the central governments through resource control of economic planning. It was also fragmented among a vast number of state production units and institutions. While the state was the de jure owner of land, work units were the de facto land users and managers. This structure made territorially organized land development difficult.

The 1986 Land Administration Law established a system in which territorial governments were granted power to perform functions in land administration. In a sense, the new system incorporated fragmented land units into unitary control of territorial governments, which had substantial power in authorizing land expropriation, land supply and rural land conversion (Wu et al, 2007). This arrangement was meant to grant certain flexibilities at lower level in order to promote local growth.

The 1998 Land Administration Law imposes the strictest land use policies, under which localities below provincial level are accorded few duties to make any important land use decision. Major tasks in land administration are taken back by provinces and the central state. These tasks include powers to approve Land Use Master Plan (LUMP), rural land conversion for urban construction, and land expropriation. Each level of the government is required to formulate a LUMP in accordance with targets set by upper level units. The LUMP is subject to approval by higher level governments, and once approved, it should be strictly enforced to assist the state in protecting arable land. This is accomplished through other important measures. For example, it is required that any expropriation of Basic Agricultural Land, no matter 
how small, requires approval by the State Council. Any conversion of other arable land for urban development requires approval by provinces or the State Council. These designations subject a large proportion of China's total arable land base to a high degree of administrative oversight, making it less attractive to potential developers. Under the new framework, municipality can only grant land uses for specific projects using extant construction land, while district no longer has legal jurisdiction in major land administration.

Re-hierarchisation of administrative structure and re-centralisation of state power in land management are further supported by a series of policies to restrict local discretion, to control capital flow, and to safeguard the interests of the disadvantaged. Local investment boom is now restricted by a tightened monetary policy and the central crackdown on 'image projects' such as wide roads, extravagant squares, and university towns. Foreign investors are also constrained by new policies to curb their speculative investment in property. Farmers are experimentally allowed to trade their land directly with developers in legal market (for more details see Wu et al, 2007). Considerable evidence now exist that reworking of the policy framework is now underway. This development accompanies a dramatic restructuring of market configuration in commodifying space in urban China.

\section{Conclusion}

This paper has argued that facing the complication of changing urban conditions, there is a resurgence of state's regulatory power, oriented towards the priority of 're-centralisation' and 're-hierarchisation' in Chinese cities. This is counter devolution 
which is widely studied in the literature of China's urban governance. Using the case of land governance, we have outlined the basic elements of a theoretical interpretation of these emerging state initiatives. We have found that in conjunction with the re-hierarchisation of institutional structures, state power has also been pervasively recentralised as new areas for central intervention are established. We have particularly examined the growing strategic importance of the central state and the restrictive local discretion in land development. It is argued that the central state still serves as an important level of local economic regulation. Because of this, it has also been an essential institutional focal point around which the various administrative reforms have been articulated so that a better regulatory result can be achieved.

Reasserting regulatory power in local economic governance should not come as a surprise. Our discussion on changing conditions inside and outside the state since the late 1990s suggests a powerful trend of fragmentation and decentralisation in the commoditised production of urban space. Three major trends are distinguishable inside the state - denationalization, destatization, and formation of new public policy that emphasizes on structural competitiveness of cities. The denationalization occurs due to the strategic significance of economic decentralisation which rearticulates state functions downwards to the local state, leading to the extension of the latter into a wide range of discretion and strategic disobedience in developing urban land. The destatization involves a shift from the central state dominance towards a new state-driven land politics in which local states partner with various actors in forming a 'growth coalition' around landed property. The formation of competitive strategies give rise to the development of 'entrepreneurial city' where the territorial state becomes more concerned with local, regional and even global competitiveness. 
Supply-driven economic policies are being linked more directly to diverse forms of infrastructure investment and property-led growth. They are attempted to enhance place-specific socio-economic assets. With these three trends of state restructuring sweeping across China, a decentralized structure has been justified as a basic institutional precondition for promoting territorial development. In this manner, urban governance is being redefined from a hierarchical, authoritative and redistributive pattern within a centrally dominated system into a territorial, competitive and developmentalist pattern with cities competing against one another to attract capital investment and central policy inclination. Outside the state, growing forces of social complexity have weakened the governing capability of the state. This is especially evident in the fusion of local state discretion with non-state forces (e.g. developer, speculator, and home purchasers) in landed property at the expense of social objective. Two results are discernible. One is social exclusion with a rising degree of marginalization. The other is spatial fragmentation either because of the failure of the cellular urban space in accommodating the fluidity of urban activities (thus informal space) or because of the inability of development control in guiding land uses. State-led development (e.g. university town, development zone, and science park) also contributes to the escalating fragmented nature of urban space.

Indeed, the decentralisation and fragmentation has grown markedly in the past decade. But even this trend is overshadowed by a wave of consolidation that is at least equally powerful. The more the structure is fragmented, the more centralized the top-level control operation might become. For example, when central policy fails because of countermeasures at the bottom, the central state is attempting to rearticulate the scalar relations so that a more centrally consolidated power can be achieved. Our 
discussions suggest that regulatory land control that emphasizes the hierarchical relationship for a more centralized power is becoming a new way of state's involvement in space commodification. For instance, central state and provinces now authorize land expropriation and rural land conversion. This function was taken away from municipality and district in 1998 who captured it from work units and their corresponding agencies at higher level in 1986. The gradual step in re-centralizing state power suggests that the state needs a consolidated control and expands its capacity, given the complications caused by the decentralized and fragmented pattern of urban growth. In a sense, the rise of re-centralized strategies may be understood as political efforts of the central state to reassert its functional importance to the fragmented process of economic governance, even though the dominance at the national level is being decentralized. Understanding this, the trend of re-centralisation and re-hierarchisation should not be conceived here as the 'legacy of authoritarianism' or 'survival of earlier pattern'. Rather, the nature of the state intervention is now redefined by the imperative of market development, making the state fundamentally different from the former counterpart. Building upon this realization, we believe decentralisation does not mean the relaxation of control; and state re-articulation upward should be read as a reactive process rather than as a linear transition from one system to another.

One central question is whether the current land governance can impose effective control? It is possibly too early to tell, but the Ministry of Construction warned the rising number of illegal land uses committed by the local state in recent years. To enhance its regulatory control, the central state speeds up its effort to curb local strategic disobedience. Key officials in such cities as Shanghai, Beijing and 
Zhengzhou have been purged because of ignoring central orders and violating national land policies. As for the study of urban governance, we argue that the emergent politics of regulation regarding land governance only presents one dimension of changes in which counter-trends might be constructed. Recentralisation happens in many other areas and at different scales. Regional strategic planning is such an area which has increasingly become a key component of political and administrative effort for central and provincial state to regain intervention and to overcome the negative effects of political fragmentation (Xu, 2007). Re-hierarchisation in economic planning system is also widely discussed. In this sense, new interpretations of 'commoditised urban transformation', especially 'commoditised production of the built environment' within contemporary Chinese cities, should be understood by underscoring the interplay between trends of decentralisation and territorialisation and counter-trends of recentralisation and hierarchisation. 